Original Research

\title{
Teenagers' Safety Smartphone Use Model Based on Health Promotion Theory
}

\section{Rizki Fitryasari, Rr Dian Tristiana, and Ah Yusuf}

Faculty of Nursing, Universitas Airlangga, Surabaya, Indonesia

\begin{abstract}
Introduction: Smartphones and teenagers in the age of technology are two very close things. Uncontrolled use of smartphones can create serious problems for teenagers, namely addiction. This research aims to build a safe smartphone use model for teenagers using a health promotion theory.

Methods: This study was an explanatory study with a cross-sectional approach. The study population was 11-18 year old teenagers in Surabaya, Indonesia who use smartphones actively. The respondents were 185 teens recruited by simple random sampling. Variables include teenager factors, technology factors, environmental factors, teenagers' thinking, self-control, commitment, and the level of smartphone use. The instrument used was an on-line questionnaire distributed through social media and then analyzed with partial least squares. The statistical afforded material for focus group discussion followed by 15 teenagers, 15 parents and 5 health workers in order to improve the model.

Results: The results showed that the level of smartphone use was affected by selfcontrol $(t=2.303 ; p=0.022)$ and commitment $(t=2.967 ; p=0.003)$. Self-control is influenced by adolescent factors ( $\mathrm{t}=3.065$; $\mathrm{p}=0.002)$, environmental factors $(\mathrm{t}=2.934 ; \mathrm{p}=0.004)$ and teenagers' thinking $(\mathrm{t}=2.522 ; \mathrm{p}=0.012)$, also self-control affects teenagers' commitment for using smartphones $(t=3.953 ; \mathrm{p}=0.000)$.
\end{abstract}

Conclusion: The model formed emphasizes the importance of establishing selfcontrol through adolescent thinking and environment factors so that they can commit to using smartphones safely.

\section{ARTICLE HISTORY}

Received: September 2, 2021

Accepted: November 14, 2021

\section{KEYWORDS}

addiction; commitment; safety smartphone's use; teenagers; teenagers' thinking

\section{CONTACT}

Rizki Fitryasari

$\triangle$ rizki-f-p-k@fkp.unair.ac.id $\equiv$ Faculty of Nursing, Universitas Airlangga, Surabaya, Indonesia

Cite this as: Fitryasari, R., Tristiana, R., D., \& Yusuf, A. (2021). Teenagers' Safety Smartphone Use Model Based on Health Promotion Theory. Jurnal Ners, 16(2). 148-154. doi: http://dx.doi.org/10.20473/in.v16i2.29650

\section{INTRODUCTION}

The use of smartphones by teenagers in the era of the Covid-19 pandemic is a necessity because all teenagers have undertaken on-line learning for school. Teenagers use smartphones actively as a means of meeting the needs of interaction with peers and most importantly for online school learning activities (Lenhart, 2015). Teenagers are required to be able to use smartphones appropriately and wisely so that they do not experience gadget addiction, especially smartphones (Cocorada, Maican, Cazan, \& Maican, 2018). The number of smartphones in use in the world today is about six billion and is forecast to grow by several hundred million in the pandemic era (O'Dea, 2021). In Indonesia, 90\% of high schools students own and use a smartphone (Machmud, 2018; Nurhayati, 2021). Teenagers in the city of Surabaya are detected using smartphones for more than 10 hours per day, which can be grouped into excessive smartphone use. Teenagers who use smartphones with high intensity have the potential to refuse activities because they tend to withdraw from social interaction (Fitryasari, Tristiana, \& Yusuf, 2020). Self-control is the main key so that adolescents do not experience addiction (Fauzi, Yusuf, \& Mundakir, 2019). Good self-control will determine the right decision-making behavior, because the ability to read the situation and be selective about environmental influences fosters good self-control abilities (Bandura, 2002; Gufron \& Riswanita, 2010). Adolescents aged 12-25 years are in a transitional phase from childhood to early adulthood and are required to be able to go through an adaptation process to be able to control themselves towards true adulthood (Kementerian Kesehatan RI, 2015; Prawirohardjo \& Sarwono, 2005). The ability of selfcontrol helps adolescents to filter out various adverse situations and conditions (Gufron \& Riswanita, 2010). Smartphone addiction can occur due to an 
individual's failure to control himself (Sun, Liu, \& Yu, 2018).

The ability of adolescents to control the use of smartphones in this study uses the perspective of the Health Promotion Model theory which focuses on the formation of self-control that affects adolescent commitment by conditioning existing thoughts through interpersonal stimulation from the environment, including health workers (Murdaugh, Parsons, \& Pender, 2018). The novelty in this model is adding the variables of self-control ability and interpersonal stimulation of health workers so that adolescents are able to form a high commitment to healthy behavior, using smartphones safely. Previous studies state that self-control in children and adolescents can be a predictor of the level of smartphone use and prevent addiction (Lee, 2015; Servidio, 2019; Troll, Friese, \& Loscheldera, 2021). This study aims to build a safe smartphone use model for adolescents based on health promotion theory.

\section{MATERIALS AND METHODS}

This study used an explanatory research design with a cross sectional approach. The study population was teenage smartphone users in Surabaya during the COVID-19 pandemic. Respondents were obtained through a purposive sampling technique and obtained 185 teenagers as research samples. Respondents were selected based on inclusion criteria of teenagers aged 11-18 years, actively using smartphones, and participating in online learning from school. Variables include teenager factors, technology factors, environmental factors, teenagers thinking, self-control, commitment, and the level of smartphone use. The research was conducted in two stages. The first stage is a meta-analysis of teenagers' factors, technological factors (smartphones), environmental factors, teenagers thinking, selfcontrol, commitment, and level of smartphone use. The results of the meta-analysis obtained structural models and strategic issues. The results of the first stage became the material for the second stage of research. Focus Group Discussion (FGD) involving teenagers, parents, and health workers. The data was then compiled to develop a safety smartphone use model for adolescents.

The instrument used for the first phase of research is a questionnaire developed by the researcher based on the previous questionnaire and theory. The teenagers factor instrument consists of demographic data (gender and age) and emotional intelligence questionnaire. The emotional intelligence questionnaire adopted from Goleman (2003) consists of five indicators: recognizing one's own emotions, managing emotions, motivating oneself, recognizing other people's emotions and building relationships (Killian, 2012). Technological factors consist of instruments to determine ownership of internet and smartphone-based tools, access to smartphone use and social media. Ownership of internet-based devices and smartphones includes indicators of the number of smartphone devices owned, types of devices and types of data packages used to access smartphones. Access to smartphone use consists of three indicators, namely the length of smartphone use in one day, the most frequent time to access a smartphone, and the reason for using a smartphone. Social media consists of the types of social media that are often accessed and the activities carried out while accessing social media. The technological factor questionnaire was developed from a questionnaire developed by Oktario (2017).

The environmental factor instrument consisted of a questionnaire about parental and teacher control, demands for schoolwork, peer influence and interpersonal stimulation from health workers. The questionnaire on parental and teacher control was modified from Li, Li, \& Newman (2013) which consisted of indicators of attention, restriction and supervision. The school assignment demand questionnaire was developed from Alfin (2017) which has been modified and consists of online school material indicators, online assignments, and online exams. The researcher modified the peer influence questionnaire based on the concept of peer function according to Santroc (2003). The interpersonal stimulation questionnaire from health workers was compiled from the concept of the role of health workers (Potter \& Perry, 2007).

Table 1. Respondents' Characteristics

\begin{tabular}{lcc}
\hline Teenagers Characteristics & Category & $\mathbf{n ( \% )}$ \\
\hline School ownership & Public & $134(72.4)$ \\
Home area (in Surabaya) & Private & $51(27.6)$ \\
& East & $83(44.9)$ \\
& North & $16(81.6)$ \\
& West & $45(24.3)$ \\
& South & $11(5.9)$ \\
School area (in Surabaya) & Central & $30(16.2)$ \\
& East & $69(37.3)$ \\
& North & $20(10.8)$ \\
& West & $34(18.4)$ \\
& South & $12(6.5)$ \\
School Grades & Central & $49(26.5)$ \\
& $7^{\text {th }}$ & $2(1.1)$ \\
& $8^{\text {th }}$ & $4(2.2)$ \\
& $9^{\text {th }}$ & $6(8.6)$ \\
& $10^{\text {th }}$ & $21(11.4)$ \\
& $11^{\text {th }}$ & $121(65.4)$ \\
& $12^{\text {th }}$ & $21(11.4)$ \\
\hline
\end{tabular}

Table 2. Distribution of Teenagers' Factor

\begin{tabular}{lcc}
\hline \multicolumn{1}{c}{ Variable } & Category & $\mathbf{n ( \% )}$ \\
\hline Gender & Male & $125(67.6)$ \\
& Female & $60(32.4)$ \\
Age (years) & 13 & $5(2.7)$ \\
& 14 & $12(6.5)$ \\
& 15 & $17(9.2)$ \\
& 16 & $101(54.6)$ \\
& 17 & $34(18.4)$ \\
Emotional Intelligence & 18 & $16(8.5)$ \\
& Low & $85(45.9)$ \\
& High & $100(54.1)$ \\
\hline
\end{tabular}


Table 3. Distribution of Technology's Factor

\begin{tabular}{|c|c|c|}
\hline Variable & Category & $\mathbf{n}(\%)$ \\
\hline \multicolumn{3}{|l|}{ Smartphone ownership } \\
\hline \multirow[t]{3}{*}{ Amount } & 1 & $134(72.4)$ \\
\hline & 2 & $47(25.4)$ \\
\hline & $>2$ & $4(2.2)$ \\
\hline \multirow[t]{3}{*}{ Device type } & Handphone & $184(99)$ \\
\hline & Laptop & $49(26.5)$ \\
\hline & Tablet & $9(4.8)$ \\
\hline \multirow[t]{4}{*}{ Data packaged used } & Daily & $10(5.4)$ \\
\hline & Weekly & $14(7.5)$ \\
\hline & Monthly & $98(52.97)$ \\
\hline & Home-Wifi & $92(49.7)$ \\
\hline \multicolumn{3}{|l|}{ Access smartphone use } \\
\hline \multirow[t]{2}{*}{$\begin{array}{l}\text { Length of use } \\
\text { (hour/day) }\end{array}$} & Mean & 8.04 \\
\hline & SD & 5.05 \\
\hline \multirow[t]{5}{*}{ Most frequent time } & Morning & $37(2.0)$ \\
\hline & Noon & $86(46.5)$ \\
\hline & Afternoon & $65(35.1)$ \\
\hline & Evening & $120(64.86)$ \\
\hline & Midnight & $30(16.2)$ \\
\hline \multirow[t]{10}{*}{ Reason for use } & School assignment & $159(85.9)$ \\
\hline & Browsing & $155(83.7)$ \\
\hline & Communication & $163(88.1)$ \\
\hline & Social Media & $159(85.9)$ \\
\hline & Leisure time & $141(76.2)$ \\
\hline & Playing game & $98(52.9)$ \\
\hline & Business & $36(19.4)$ \\
\hline & Self-actualization & $19(10.2)$ \\
\hline & Lifestyle & $28(15.1)$ \\
\hline & $\begin{array}{c}\text { Watching Korean } \\
\text { movies }\end{array}$ & $1(0.5)$ \\
\hline \multicolumn{3}{|l|}{ Social media access } \\
\hline \multirow[t]{7}{*}{ Application } & Facebook & $21(11.3)$ \\
\hline & WhatsApp & $167(90.3)$ \\
\hline & Line & $68(36.7)$ \\
\hline & Instagram & $160(86.4)$ \\
\hline & Snap-chat & $16(8.6)$ \\
\hline & You tube & $133(71.8)$ \\
\hline & TikTok & $22(11.8)$ \\
\hline \multirow[t]{6}{*}{ Frequent activity } & Status Update & $53(28.6$ \\
\hline & Photo Upload & $28(15.1$ \\
\hline & Comment/like & $112(60.5$ \\
\hline & Profile update & 31 (16.7) \\
\hline & Browsing & $162(87.5)$ \\
\hline & Chatting & $9(4.8)$ \\
\hline
\end{tabular}

The adolescent self-thinking instrument consists of four indicators, consist of benefits, obstacles, beliefs, and the impact of smartphone use on adolescents. This instrument was developed based on the concept of health promotion and a smartphone using a questionnaire (Murdaugh et al., 2018; Van Deursen, Bolle, Hegner, \& Kommers, 2015). The adolescent self-control instrument consists of three indicators, namely cognitive control, behavioral control, and decision making modified from the Self Control Model and a smartphone using a questionnaire (Li et al., 2013; Van Deursen et al., 2015). The smartphone use instrument was developed from the smartphone addiction scale instrument according to Haug (2015). All questionnaires have been tested for reliability and validity as a pilot sample on 30 respondents. The test results show that the components of the questionnaire are valid and reliable ( $p>0.73)$.

Data collection at the first stage was performed using an online questionnaire via a Google form and is distributed through social media. A written explanation of the objectives, benefits and procedures of the research is clearly informed. All respondents who agreed to participate in the study had to obtain parental consent by signing an online informed consent, and consent was confirmed by telephone. The second stage of the research was FGD which involved 15 teenagers, 15 parents and 5 health workers. The FGD was conducted by describing the results of the first phase of the research and discussing the main questions (Table 1 ).

Analysis of the data obtained in the first stage was analyzed using the Partial Least Square (PLS) test. PLS is used to analyze the influence between variables which is determined by the $t$-statistic value $(t>1.96)$, while the direction of influence is determined by the path coefficient $(-/+)$. The result will be used as material (question) for FGD. The data of the FGD were recorded, transcribed, and analyzed using the Braun and Clarke Thematic Analysis approach. These stages were understanding the data, generating initial codes, searching for themes, reviewing themes, defining, and naming themes and producing the report. The results were then compiled to develop the models.

Ethics clearance has been approved and obtained from the Ethics Committee of the Faculty of Nursing Universitas Airlangga with the number: 2018-KEPK.

\section{RESULTS}

The characteristics of the respondents are described in table 1 , the majority of teenagers attend public schools located in East and Central Surabaya, most are currently studying at the $11^{\text {th }}$ grade $\left(2^{\text {nd }}\right.$ of Senior High School) and live in eastern and western Surabaya. Tables 2, 3 and 4 describe the distribution of research variables. Table 2 describes the teenagers' factors, most of them were male and aged 16 years with varying levels of emotional intelligence from low to high. Table 3 details that almost all teenagers have a smartphone-based device, especially mobile phones with monthly data packages used and also home wifi. Respondents on average use smartphones for more than 8 hours a day, especially during the noon-day and night. The reasons for using smartphones mostly were to communicate, do schoolwork, access social media, and browse information. The most frequently accessed social media by respondents are WhatsApp and Instagram. Most smartphone usage activities are for browsing and giving comments or likes on social media. Table 4 illustrates that the influence of parents, demands for school assignments and 
Table 4. Distribution of Environmental Factor, Teenager's Thinking, Self-Control, Commitment, and Smartphone Usage

\begin{tabular}{|c|c|c|c|}
\hline \multirow{2}{*}{ Variable } & \multicolumn{3}{|c|}{ Category (n(\%)) } \\
\hline & Low & Middle & High \\
\hline \multicolumn{4}{|l|}{ Environmental factor } \\
\hline Parent's influence & $24(13)$ & $47(25.4)$ & $114(61.6)$ \\
\hline Teacher's influence & $89(48.1)$ & $45(24.3)$ & $51(27.6)$ \\
\hline School assignment demand & $4(2.2)$ & $65(35.1)$ & $116(62.7)$ \\
\hline Peer's influence & $47(25.4)$ & $71(38.4)$ & $67(36.2)$ \\
\hline Health worker's interpersonal stimulation & $61(33)$ & $45(24.3)$ & $79(42.7)$ \\
\hline \multicolumn{4}{|l|}{ Teenager's thinking } \\
\hline Advantages & $3(1.6)$ & - & $182(98.4)$ \\
\hline Barriers & $9(4.9)$ & - & $17695.1)$ \\
\hline Belief & $0(0)$ & - & $185(100)$ \\
\hline Effect & $4(2.2)$ & - & $181(97.8)$ \\
\hline \multicolumn{4}{|l|}{ Self-control } \\
\hline Cognitive & $30(16.2)$ & $81(43.8)$ & $74(40)$ \\
\hline Behavior & $5(2.7)$ & $53(28.6)$ & $127(68.6)$ \\
\hline \multicolumn{4}{|l|}{ Commitment } \\
\hline Decision-making & $6(3.2)$ & $57(30.8)$ & $122(65.9)$ \\
\hline \multicolumn{4}{|l|}{ Level of gadget addiction } \\
\hline Impaired physical activity & 55 (29.7) & $94(50.8)$ & $36(19.5)$ \\
\hline Overuse & $87(47)$ & $68(36.8)$ & $30(16.2)$ \\
\hline Withdrawal & 92 (49.7) & $61(33)$ & $32(17.3)$ \\
\hline Anticipatory & $113(61.1)$ & $56(30.3)$ & $16(8.6)$ \\
\hline Cyberspace oriented & $91(49.2)$ & $61(33)$ & $33(17.8)$ \\
\hline Tolerance & $39(21.1)$ & $81(43.8)$ & $65(35.1)$ \\
\hline
\end{tabular}

Table 5. Final Model of Hypothesis Test on The Development of Teenagers' Safety Smartphone Use Model

\begin{tabular}{|c|c|c|c|c|}
\hline Variable & Path-coefficient & $\mathbf{t}$ & p-value & \\
\hline Teenager's factor (X1) $\rightarrow$ Teenager's thinking (Y1) & 0.293 & 3.970 & 0.000 & Significant \\
\hline Teenager's factor (X1) $\rightarrow$ Self-control (Y2) & 0.272 & 3.065 & 0.002 & Significant \\
\hline Teenager's factor (X1) $\rightarrow$ Commitment (Y3) & 0.165 & 2.244 & 0.025 & Significant \\
\hline Teenager's factor $(\mathrm{X} 1) \rightarrow$ Smartphone usage (Y4) & -0.055 & 0.933 & 0.351 & Insignificant \\
\hline Technology's factor (X2) $\rightarrow$ Teenager's thinking (Y1) & 0.039 & 0.519 & 0.604 & Insignificant \\
\hline Technology's factor (X2) $\rightarrow$ Self-control (Y2) & -0.248 & 4.094 & 0.000 & Significant \\
\hline Technology's factor (X2) $\rightarrow$ Commitment (Y3) & 0.024 & 0.250 & 0.803 & Insignificant \\
\hline Technology's factor (X2) $\rightarrow$ Smartphone usage (Y4) & 0.612 & 10.331 & 0.000 & Significant \\
\hline Environment factor $(\mathrm{X} 3) \rightarrow$ Teenager's thinking (Y1) & 0.224 & 3.294 & 0.001 & Significant \\
\hline Environment factor (X3) $\rightarrow$ Self-control (Y2) & 0.217 & 2.934 & 0.004 & Significant \\
\hline Environment factor (X3) $\rightarrow$ Commitment (Y3) & -0.092 & 0.940 & 0.348 & Insignificant \\
\hline Environment factor (X3) $\rightarrow$ Smartphone usage (Y4) & -0.030 & 0.476 & 0.634 & Insignificant \\
\hline Teenager's thinking (Y1) $\rightarrow$ Self-control (Y2) & 0.218 & 2.522 & 0.012 & Significant \\
\hline Teenager's thinking (Y1) $\rightarrow$ Smartphone usage (Y4) & -0.073 & 1.114 & 0.266 & Insignificant \\
\hline Self-control (Y2) $\rightarrow$ Commitment (Y3) & 0.372 & 3.953 & 0.000 & Significant \\
\hline Self-control (Y2) $\rightarrow$ Smartphone usage (Y4) & -0.183 & 2.303 & 0.022 & Significant \\
\hline Commitment $(\mathrm{Y} 3 \rightarrow$ Smartphone usage (Y4) & -0.201 & 2.967 & 0.003 & Significant \\
\hline
\end{tabular}

interpersonal stimulation from health workers according to respondents has a high value as an environmental factor in smartphone use, while the influence of teachers has a low value. Meanwhile, teenagers' thinking, which consists of four categories, has almost all high scores related to the benefits, barriers, beliefs, and consequences of using smartphones. Teenagers' self-control variables both cognitively and behaviorally are dominated by high criteria, although there is a small proportion of teenagers' cognitive control with low scores. Meanwhile, the youths' commitment to decision making in the use of smartphones is high. Smartphone users are described in the level of gadget addiction which is described in six indicators with the dominance of low addiction levels in almost all categories, however obtained data shows that the tolerance indicator has a number that needs to be considered because it is classified as a high addiction level.

Based on table 5, the research hypothesis can be explained. Teenagers' factors have an effect on increasing teenagers thinking $(\mathrm{t}=3.97 ; 0.293$; $\mathrm{p}=0.000)$, increasing self-control $(\mathrm{t}=3.065 ; 0.272$; $\mathrm{p}=0.002$ ) and increasing teenagers' commitment $(\mathrm{t}=2.244 ; 0.165 ; \mathrm{p}=0.025)$, but has no effect on smartphone use $(\mathrm{t}=0.933 ; \mathrm{p}=0.351)$. Technological factors have an effect on decreasing self-control $(\mathrm{t}=4.094 ;-0.248 ; \mathrm{p}=0.000)$ and increasing the use of smartphones $(\mathrm{t}=10.331 ; 0.612 ; \mathrm{p}=0.000)$ however, it has no effect on teenagers' thinking $(t=0.519$; $\mathrm{p}=0.604)$ and commitment ( $\mathrm{t}=0.25 ; \mathrm{p}=0.803)$. Environmental factors have an effect on increasing thinking ( $\mathrm{t}=3.294 ; 0.224 ; \mathrm{p}=0.001)$ and self-control $(\mathrm{t}=2.934 ; 0.217 ; \mathrm{p}=0.004)$, but have no effect on commitment $(\mathrm{t}=0.940 ; \mathrm{p}=0.348)$ and smartphone 


\section{R. FITRYASARI ET AL.}

Table 6. Result of Development Model of Teenagers' Safety Smartphone Use

\begin{tabular}{|c|c|}
\hline Variable & Things to develop \\
\hline Teenagers' factor & $\begin{array}{l}\text { Assessing teenager emotional intelligence, especially self-emotional management, self- } \\
\text { motivation in smartphone use }\end{array}$ \\
\hline Technology factor & $\begin{array}{l}\text { Assessing smartphone's access (availability of devices and internet data packages, length of } \\
\text { screen time, types of content and reasons for use) that can be used by teenagers }\end{array}$ \\
\hline Environment factor & $\begin{array}{l}\text { Assessing the important role of peers (content accessed, activity on social media), information } \\
\text { provided by health workers and parental control in smartphone use }\end{array}$ \\
\hline Teenagers' thinking & $\begin{array}{l}\text { Identify level of the teenager's understanding of the benefits, beliefs, barriers and impacts of } \\
\text { smartphone use related to academic and non-academic activities }\end{array}$ \\
\hline & smartphones \\
\hline Teenagers' self-control & $\begin{array}{l}\text { Identify the level of teenager self-control abilities, both cognitive and behavioral in smartphone } \\
\text { use }\end{array}$ \\
\hline & safely \\
\hline tment & $\begin{array}{l}\text { Identify the teenager's commitment especially decision making based on usage priorities } \\
\text { Building a positive commitment of youth in using smartphones safely }\end{array}$ \\
\hline Smartphone's use & $\begin{array}{l}\text { Identify the frequency of use in one day and the level of dependence of teenagers in smartphone } \\
\text { use }\end{array}$ \\
\hline
\end{tabular}

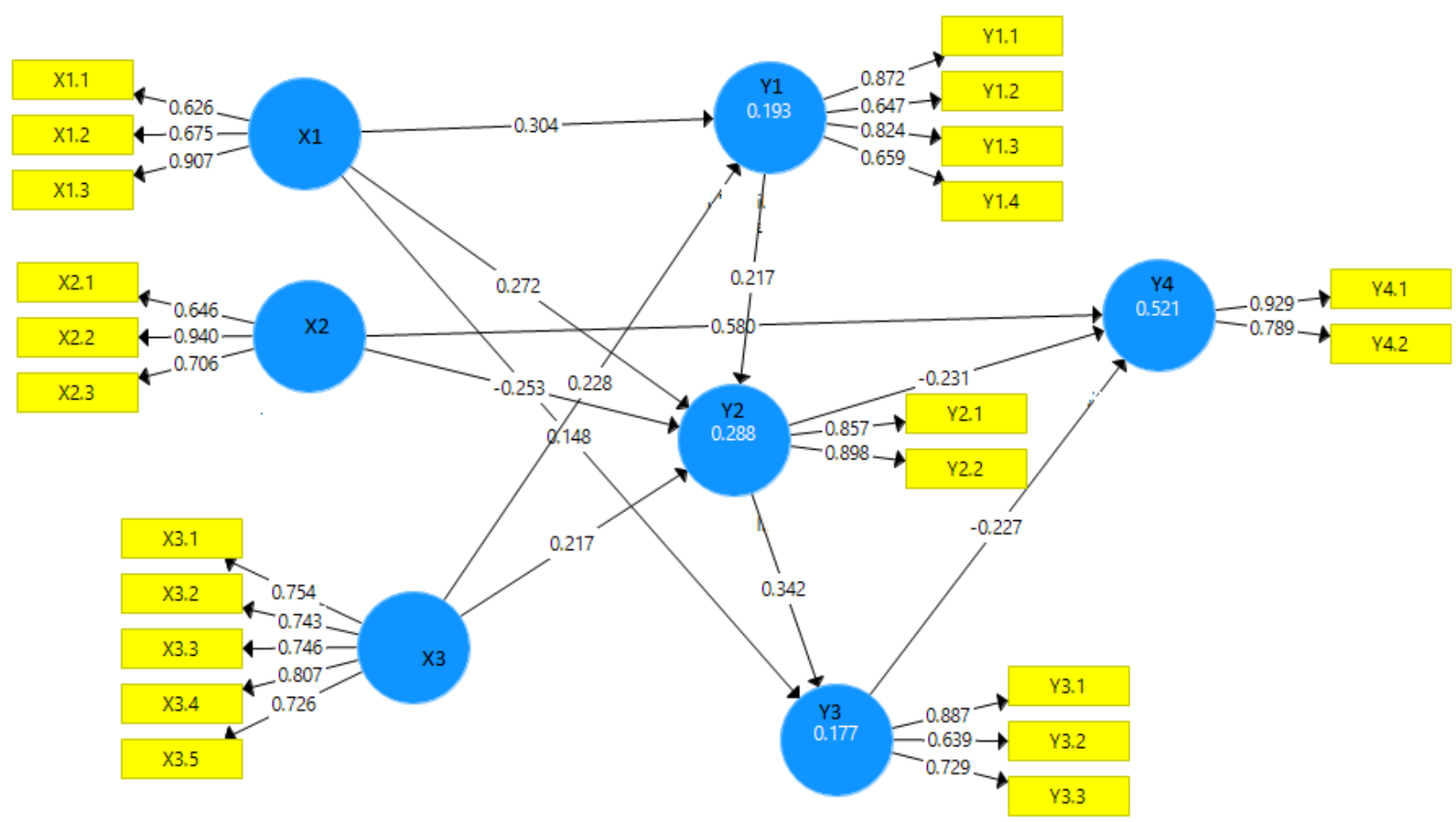

Figure 1. The Development of Teenagers' Safety Smartphone Use Model

use(t). $=0.476 ; \mathrm{p}=0.634)$. Teenagers' thinking has an effect on increasing teenagers' self-control $(\mathrm{t}=2.522$; $0.218 ; \mathrm{p}=0.012$ ) but has no effect on smartphone use $(t=1.114 ; p=0.266)$. Self-control has an effect on increasing commitment $(\mathrm{t}=3.953 ; 0.372 ; \mathrm{p}=0.000)$ and decreasing smartphone use $(\mathrm{t}=2.303 ;-0.183$; $\mathrm{p}=0.022$ ). Commitment has an effect on reducing the use of smartphones in teenagers $(\mathrm{t}=2.967 ;-0.201 ; \mathrm{p}$ $=0.003$ ). The findings can be explained whereby the model emphasizes the importance of establishing self-control through teenagers' thinking so they can commit to using a smartphone safely. Teenagers' thinking will be formed through controlling environmental factors, especially the influence of peers and interpersonal stimulation from health workers and by optimizing teenagers' individual factors, especially emotional intelligence.
Based on Figure 1, it can be explained that teenagers' factors and environmental factors affect the formation of teenagers thinking by $19.3 \%$, and together with technological factors can increase the formation of self-control by $28.8 \%$. Meanwhile, teenagers' commitment is built from teenagers' factors and self-control of $17.7 \%$. Eventually, technology factors, self-control and teenagers' commitment control the use of smartphones by $52.1 \%$ in teenagers

During the FGD, it can be concluded that several things that must be developed in this model are: 1) Assess teenagers' factors, technology and the environment, 2) Identify the level of teenagers' thinking, self-control ability and teenagers' commitment related to smartphone use, 3) Provide stimulation to create positive teenagers thinking and self-control in the safe use of smartphones, 4) Build a 
positive commitment for using smartphones safely (Table 6).

\section{DISCUSSION}

The safe use of smartphones in teenagers in was determined by two important variables with a negative relationship, namely teenager self-control and teenager commitment. High self-control and commitment can reduce or limit the use of smartphones in teenagers. Self-control as a result of cognitive considerations that are embodied in behavior in achieving certain goals (Gufron \& Riswanita, 2010). Teenagers in this study had high self-control in using smartphones with the aim of doing school assignments and communicating with family, friends, and teachers. In addition, teenagers in the FGD process also stated that it is very important to limit the time they use smartphones in one day because they realize that using the device too much can affect their physical condition, such as eyes feeling tired, laziness in doing other activities and being bound to always using a smartphone. Understanding the main purpose of using internetbased tools is to form good self-control behaviorally so that teenagers are able to use smartphones without becoming addicted. The results of this study are in line with the results of research on school-age teenagers in South Korea, that self-control is related to the level of smartphone addiction (Cocorada et al., 2018; Sok, 2019; Sun et al., 2018). Good self-control also fosters teenager's commitment in making decisions to use smartphones with clear goals. The data also shows that more than $80 \%$ of teenagers use smartphones to do schoolwork and search for information on the internet (Lenhart, 2015; Muflih, Hamzah, \& Purniawan, 2017). Data collection was carried out during the Covid-19 pandemic, where all teenagers went to school online (using internet-based tools). This situation strongly leads teenagers to use smartphones for the sake of learning at school and not just for the sake of having fun or spending their free time. During the FGD, teenagers said they were committed to being disciplined in limiting the use of smartphones by installing an application that functioned to remind them of the length of time of use, asking parents for help to remind them if they were too active with smartphones, teenagers were also very happy to remind each other not to use a smartphone for too long outside of school activities.

Self-control in teenagers is influenced by teenagers' thoughts related to the benefits, barriers, beliefs, and consequences of smartphone use. Thought is the beginning of the process of selfregulation. The inability to build self-regulation can lead to the risk of smartphone addiction in teenagers (Van Deursen et al., 2015). Self-regulation helps teenagers to be able to identify the problems they face and determine the selection of appropriate actions in solving problems (Alhidayah, 2017; Bandura, 2002). Teenagers in this study think about the benefits and believe that the use of smartphones is very helpful in completing school assignments, communicating, and interacting virtually with family, friends, and teachers. Variations in the internet network that are not smooth are expressed as obstacles experienced and related understanding due to the use of smartphones that are not related to completing school assignments fosters self-regulation skills in the form of self-control in smartphone use. The obstacles faced are one of the triggers for the creativity of smartphone users (Chun, 2018). The results also explain that teenagers use smartphones for pleasure, such as interacting through social media, playing games, and filling their spare time, but the thoughts are formed that smartphone use should be used for learning activities which make teens have good selfcontrol and are committed to limiting their time of use of smartphones without having to experience heavy gadget addiction.

Teenagers' thinking as the basis for the formation of self-control is influenced by teenager factors and environmental factors. One of the dominant environmental factors is the presence of interpersonal stimuli, in the form of information about the use of smartphones from outside the teenager. The majority of information sources are from parents, internet, schools (school health unit) and health workers who come to school. Teenagers are an age who are thirsty for information and getting information from the right sources will help them have the right mindset regarding smartphone use. The findings of this study support the Health Promotion Model Theory, that the right input of information on individuals will foster thoughts related to benefits, beliefs, consequences, and obstacles in deciding an action. This study explains that sources of information from parents, schools (UKS) and health workers are sources of appropriate and accountable information. During the FGD the youth conveyed that the information they received and was very helpful for teenagers, including how to use smartphones, good content or sites for teenagers to access related to school assignments, seeking entertainment, increasing knowledge, how to limit smartphone use, information about the impact of excessive smartphone use, and how to overcome dependence on smartphone use. Teenagers who get the right information will be helped in developing the right thinking. Although thinking does not directly make teenagers use smartphones safely, the thoughts help teenagers have good self-control to commit and decide to use smartphones safely and not experience addiction.

The limitation of this study was that it only involved teenagers in big cities who have wide and good internet access, so it requires additional respondents in small cities to be more generalized for all teenagers in both big and small cities in Indonesia. However, the results of this study have highlighted that good self-control can be one of the factors that prevents smartphone addiction in teenagers.

\section{CONCLUSION}


The model emphasizes the importance of self-control in forming teenagers' commitment to using smartphones. High self-control is the result of teenager thinking that will be formed through controlling environmental factors, especially the influence of peers and interpersonal stimulation from health workers and by optimizing teenagers' individual factors, especially emotional intelligence. This model can be the basis for providing guidelines for the safe use of smartphones for teenagers.

\section{REFERENCES}

Alhidayah. (2017). The influence of smartphone use intensity toward social interaction in collage students. Jurnal Riset, 2(2).

Bandura, A. (2002). Self efficacy: The Exercise of Control. W. H. Freeman \& Company.

Chun, J. S. (2018). Conceptualizing effective interventions for smartphone addiction among Korean female adolescents. Children and Youth Services Review, 84(November 2017), 35-39. https://doi.org/10.1016/j.childyouth.2017.11.013

Cocorada, E., Maican, C. I., Cazan, A. M., \& Maican, M. . (2018). Assessing the smartphone addiction risk and its associations with personality traits among adolescents. Children and Youth Services Review 93, 345-354.

Fauzi, M., Yusuf, A., \& Mundakir. (2019). Predictive Risk Factors of Smartphone Addiction in Adolescents: A Systematic Review. Journal Ners, 14(3).

https://doi.org/http://dx.doi.org/10.20473/jn.v1 $4 \mathrm{i} 3.17110$

Fitryasari, R., Tristiana, R. D., \& Yusuf, A. (2020). Teenager' s thought is related to self-control in safe smartphone use during the covid-19 pandemic. Journal of Global Pharma Technology, 12(9), 280286.

Gufron, M. N., \& Riswanita, R. (2010). Psychology Theorys. Ar Ruzz Media.

Haug, S., Castro, R. P., Kwon, M., Filler, A., Kowatsch, T., \& Schaub, M. P. (2015). Smartphone use and smartphone addiction among young people in Switzerland. Journal of Behavioral Addictions, 4(4), 299-307.

https://doi.org/10.1556/2006.4.2015.037

Kementerian Kesehatan RI. (2015). Rencana Strategis Kementerian Kesehatan RI Tahun 2015-2019 (Keputusan Menteri Kesehatan Republik Indonesia Nomor HK.02.02/MENKES/52/2015.

Killian, K. (2012). Development and validation of the emotional self-awareness questionnaire: a measure of emotional intelligence. Journal of Marital and Family Therapy, 38(3), 502-514. https://doi.org/10.1111/j.17520606.2011.00233.x

Lee, J. (2015). Effects of self-control and school adjustment on smartphone addiction among elementary school students. International Journal of Contents, 11(3).

Lenhart, A. (2015). Mobile Access Shifts Social Media
Use and Other Online Activities. Pew Research Center: Internet, Science \& Tech.

Li, X., Li, D., \& Newman, J. (2013). Parental Behavioral and Psychological Control and Problematic Internet Use Among Chinese Adolescents: The Mediating Role of Self-Control. Cyberpsychology, Behavior, and Social Networking, 16(6), 442-447. https://doi.org/10.1089/cyber.2012.0293

Machmud, K. (2018). The Smartphone Use in Indonesian Schools: The High School. Journal of Arts \& Humanities, 7(3), 33-40. https://doi.org/10.18533/journal.v7i3.1354

Muflih, M., Hamzah, H., \& Purniawan, W. A. (2017). Smartphone user and social interaction in senior high school. Idea Nursing Journal, 8(1).

Murdaugh, C. L., Parsons, M. A., \& Pender, N. J. (2018). Health Promotion in Nursing Practice (8th ed.). Pearson.

Nurhayati, H. (2021). Number of smartphone users in Indonesia from 2017 to 2020 with forecasts until 2026. Statista.

O'Dea, S. (2021). Smartphone users worldwide 20162021. Statista.

Oktario, A. (2017). Relationship between smartphone use intensity and motivation in collage students. Thesis. Universitas Sanata Dharma.

Potter, P. ., \& Perry, A. . (2007). Fundamental Nursing: Concepts, Process, and Practice (6th editio). Mosby Year Book.

Prawirohardjo, \& Sarwono. (2005). Midwivery Science. Bina Pustaka.

Servidio, R. (2019). Self-control and problematic smartphone use among Italian University students: The mediating role of the fear of missing out and of smartphone use patterns. Current Psychology, 40, 4101-4111. https://doi.org/10.1007/s12144019-00373-z

Sok, S. R. (2019). Differences of Self-Control, Daily Life Stress, and Communication Skills between Smartphone Addiction Risk Group and General Group in Korean Nursing Students. 1-9.

Sun, J., Liu, Q., \& Yu, S. (2018). Child neglect, psychological abuse and smartphone addiction among Chinese adolescents: The roles of emotional intelligence and coping style. Computers in Human Behavior, 90(September 2017), 74-83. https://doi.org/10.1016/J.CHB.2018.08.032

Troll, E., Friese, M., \& Loscheldera, D. (2021). How students' self-control and smartphone-use explain their academic performance. Computers in Human Behavior, 117. https://doi.org/https://doi.org/10.1016/j.chb.20 20.106624

Van Deursen, A. J. A. M., Bolle, C. L., Hegner, S. M., \& Kommers, P. A. M. (2015). Modeling habitual and addictive smartphone behavior: The role of smartphone usage types, emotional intelligence, social stress, self-regulation, age, and gender. Computers in Human Behavior, 45, 411-420. https://doi.org/10.1016/j.chb.2014.12.039 